\title{
ARCHEOLOGIA, PAMIEĆ́, SZTUKA. ARCHEOETNOGRAFIA I SZTUKA OKOPOWA ZWIĄZANA $Z$ OBOZEM JEŃCÓW WOJENNYCH I INTERNOWANYCH W TUCHOLI, WOJ. KUJAWSKO-POMORSKIE
}

\author{
ARCHAEOLOGY, ART, MEMORY: ARCHAEO-ETHNOGRAPHY \\ AND TRENCH ART FROM A PRISONER OF WAR \\ AND INTERMENT CAMP IN TUCHOLA, POLAND
}

\author{
Dawid Kobiatka \\ orcid.org/0000-0003-3806-4408 \\ Instytut Archeologii i Etnologii Polskiej Akademii Nauk \\ Al. Solidarności 105, 00-140 Warszawa, Poland \\ dawidkobialka@wp.pl
}

\begin{abstract}
Lidar-derivatives gathered during the realization of IT System of Country's Protection Against Extreme Hazards (so-called ISOK programme) have initialized the non-invasive archaeological research concerning the preservation of the relicts of the former prisoner of war and internment camp in Tuchola, Poland. The camp functioned during the Great War (1914-1918) and the Polish-Soviet War (1919-1921). This paper discusses and summaries the preliminary results of this research. It argues that the use of ethnographic methods can supplement and enrich the historical records related to the camp. The article discusses in detail the assemblage of material culture made, remade, or personalized by prisoners and internees documented during the research. These artefacts are unique examples of trench art. Discussion concerning the objects is the main goal of this paper. They are the first examples of the trench art related to the Tuchola camp analyzed in the archaeological literature.
\end{abstract}

KEY WORDS: Tuchola, prisoner of war camp, internment camp, archaeology, memory, trench art

\section{ARCHEOETNOGRAFIA OBOZU JEŃCÓW WOJENNYCH I INTERNOWANYCH W TUCHOLI}

W 2012 roku na rządowej platformie geoinformacyjnej geoportal.gov.pl po raz pierwszy umieszczono w wolnym dostępie pochodne lotniczego skanowania lase- 
rowego (LSL), które zostały zebrane w ramach Informatycznego Systemu Osłony Kraju przed nadzwyczajnymi zagrożeniami (ISOK). Wraz z upływem miesięcy i lat udostępniano w formie cieniowego modelu terenu kolejne obszary Polski (por. Wężyk, 2014). Chociaż projekt nie był realizowany pod kątem rozpoznania i dokumentacji dziedzictwa kulturowego, to te dane miały ilościowe i jakościowe implikacje dla polskiej archeologii. W trakcie przeglądania owych pochodnych archeolodzy oraz osoby niemające wiele wspólnego $\mathrm{z}$ archeologią zaczęły odkrywać tysiące wcześniej nieznanych śladów działalności człowieka z przeszłości - zaczynając od stanowisk neolitycznych, a kończąc na śladach I i II wojny światowej (np. Zapłata, Szady, Stefańczyk, 2014; Wroniecki, Jaworski, Kostyrko, 2015; Kostyrko, Kajda, Wroniecki, Lokś, 2016; Karczewska, Karczewski, 2018). Podobnie historia wygląda w przypadku materialnych pozostałości po obozie jeńców wojennych i internowanych, który został założony na obrzeżach Tucholi (woj. kujawsko-pomorskie) (ryc. 1). Gdy w 2014 roku wraz z Mikołajem Kostyrko preglądaliśmy dane z ISOK-u na platformie geoportal.gov.pl, naszą uwagę zwróciły rzędy podłużnych obiektów rysujące się na południowy wschód od Tucholi (ryc. 2). Okrycie to stało się przyczynkiem do zajęcia się bliżej stanem zachowania obiektów związanych z obozem jeńców wojennych $\mathrm{i}$ internowanych $\mathrm{w}$ Tucholi.

Historia obozu w Tucholi jest dobrze opisana w polskiej historiografii, co jest wynikiem studiów toruńskich historyków Zbigniewa Karpusa i Waldemara Rezmera (np. 1997, 1998; Karpus, Wiszka, Sribniak, 2007). Natomiast kwestia śmiertelności jeńców w Tucholi jest przedmiotem osobnych analiz Alicji Marcinkiewicz (np. 2016). Na potrzeby niniejszego opracowania nie ma powodu, aby powtarzać wielu znanych i już opisanych aspektów tucholskiego obozu. Z historycznego punktu widzenia należy przede wszystkim zaznaczyć, że Niemcy założyli jeszcze w 1914 roku na obrzeżach Tucholi obóz, w którym przetrzymywano pojmanych żołnierzy rosyjskich. $Z$ czasem w tucholskim ośrodku więziono Rumunów, Anglików, Włochów, a nawet żołnierzy amerykańskich. Obóz opustoszał wraz z końcem I wojny światowej. Po przejęciu Pomorza pozostałościami obozowymi zainteresowały się także polskie władze. Już między majem 1920 a majem 1921 roku w obozie przetrzymywano Ukraińców. Od sierpnia 1920 do października 1921 więziono w nim żołnierzy rosyjskich ujętych podczas walk polsko-bolszewickich. W ostatnim etapie, między wrześniem 1921 roku a styczniem 1923 roku, w Tucholi internowano niewielką grupę Rosjan (więcej w: Karpus, Rezmer, 1997). Słowem historia obozu w Tucholi to w rzeczywistości dzieje kilku ośrodków, w których na przestrzeni niespełna dekady oraz $\mathrm{w}$ trakcie dwóch konfliktów zbrojnych (pierwsza wojna światowa, wojna polsko-bolszewicka) przetrzymywano jeńców wojennych i internowanych. Właśnie część dziedzictwa obozowego udało się zarejestrować już w 2014 roku (ryc. 3). 

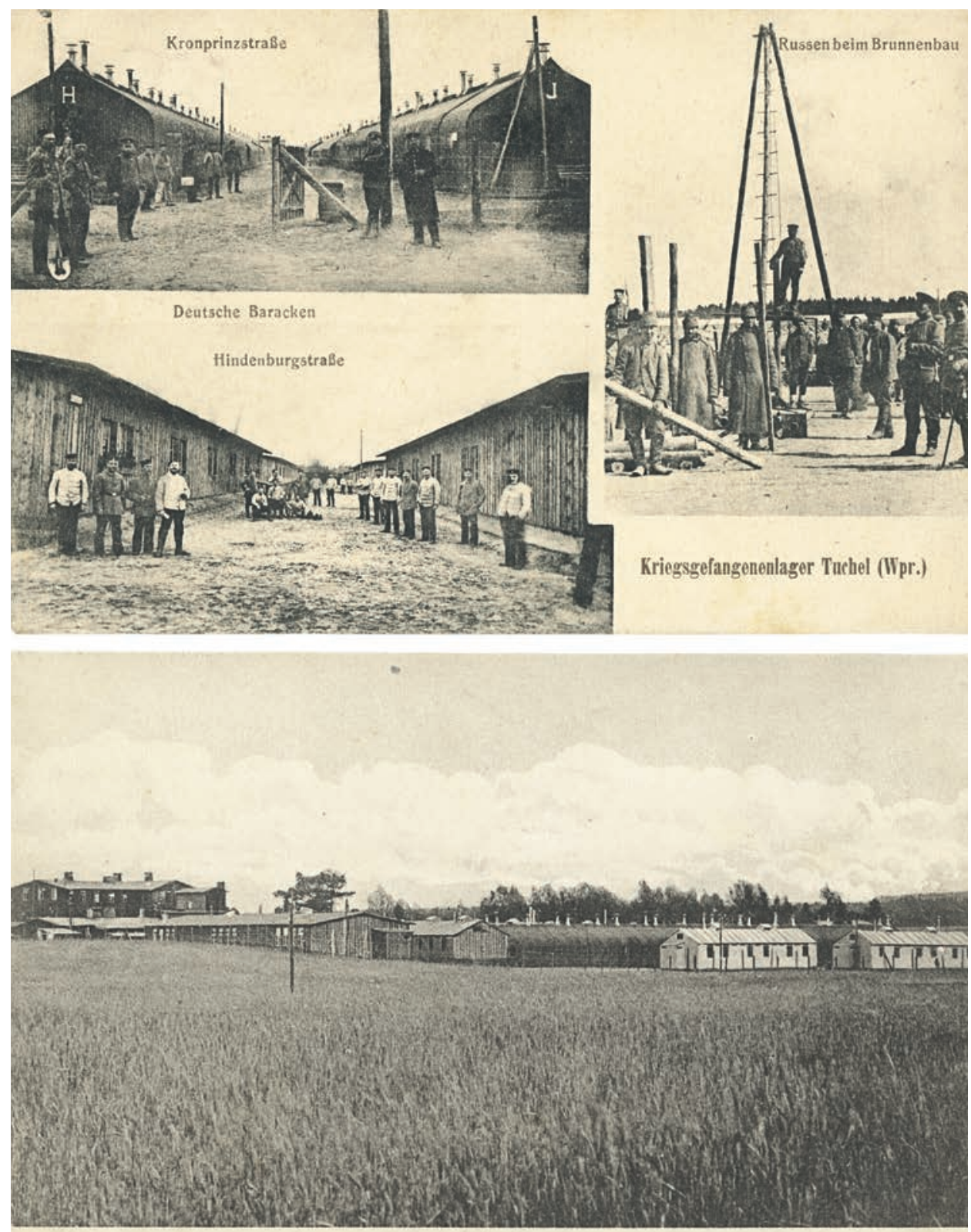

Tuchel, Westpr. Gefangenenlager II,

Ryc. 1. Niemieckie pocztówki propagandowe prezentujące poszczególne strefy obozowe w trakcie trwania Wielkiej Wojny (zbiory prywatne Zenona Wędzickiego)

Fig. 1. German propaganda postcards presenting selected camp zones during the Great War (private collection of Zenon Wędzicki) 


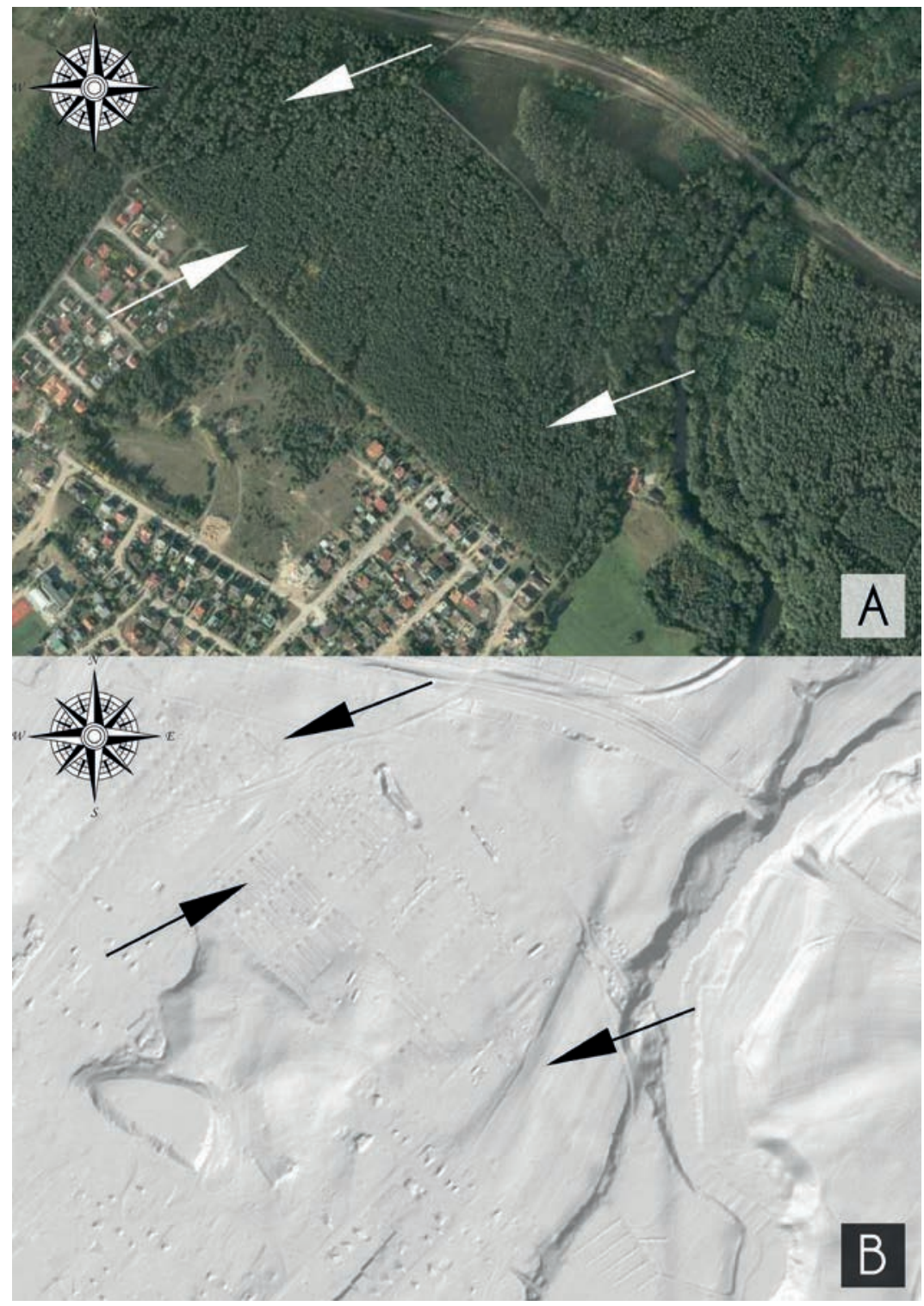

Ryc. 2. Pierwsze obiekty obozowe zauważone w 2014 roku na platformie geoportal.gov. pl. A - ortofotomapa ukazująca tereny dawnego obozu jeńców wojennych i internowanych w Tucholi (źródło: geoportal.gov.pl). B - model cieniowany udostępniony na platformie geoportal.gov.pl - strzałki wskazują przykładowe ślady ziemianek obozowych (źródło: geoportal.gov.pl)

Fig. 2. The first camp structures noticed in 2014 on the geoportal.gov.pl platform. A - orthophotomap showing the area of the former prisoner of war camp and interned in Tuchola (source: geoportal.gov.pl). B - shaded model available on the geoportal.gov.pl platform - arrows indicate examples of traces of camp dugouts (source: geoportal.gov.pl) 

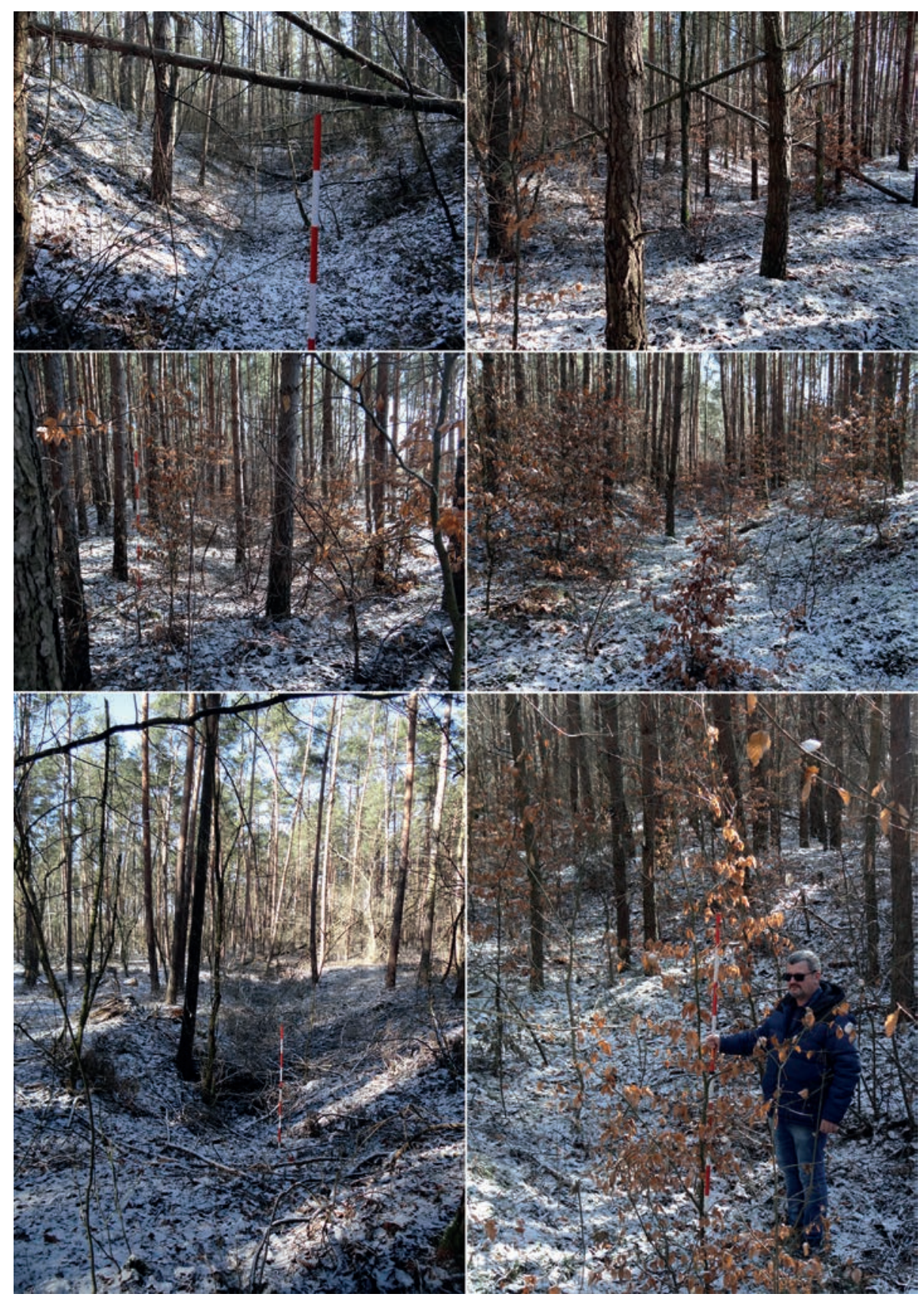

Ryc. 3. Stan zachowania obiektów obozowych in situ rozpoznanych na pochodnych lotniczego skanowania laserowego w 2014 roku na platformie geoportal.gov.pl (fot. Dawid Kobiałka)

Fig. 3. The condition of camp structures in situ recognized on derivatives of airborne laser scanning in 2014 on the geoportal.gov.pl platform (photo by Dawid Kobiałka) 
Dalsze działania zmierzające do rozpoznania i dokumentacji różnorodnych wymiarów dziedzictwa tucholskiego ośrodka były możliwe w latach 2016-2018 (por. Kobiałka, Kostyrko, Kajda, 2016, 2017). W ramach realizacji projektu naukowego „Między pamięcią a zapomnieniem: archeologia a XX-wieczne dziedzictwo militarne na terenach zalesionych" pozyskano pochodne lotniczego skanowania laserowego pod postacią chmury punktów dla terenu obozu. Pozwoliło to na wytworzenie pochodnych w postaci numerycznego modelu terenu oraz jego ponowną reklasyfikację w celu uzyskania kolejnego modelu, mając na uwadze obecność obiektów archeologicznych w badanej przestrzeni (por. Kiarszys, Szalast, 2014) (ryc. 4). Także prospekcja lotnicza z wykorzystaniem bezzałogowego statku powietrznego przyczyniła się do dokumentacji struktur obozowych (ryc. 5). Ważnymi elementami realizacji projektu były kwerendy archiwalne dotyczące funkcjonowania obozów w Tucholi. Natomiast ostatnią składową były poszukiwania opowieści, wspomnień, dokumentów i artefaktów dotyczących obozu, jeńców, jego strażników, które mogły zachować się do wśród lokalnej społeczności. W tym aspekcie wykorzystano etnografię jako metodę badawczą (pogłębiony wywiad etnograficzny) (por. Konecki, 2018).
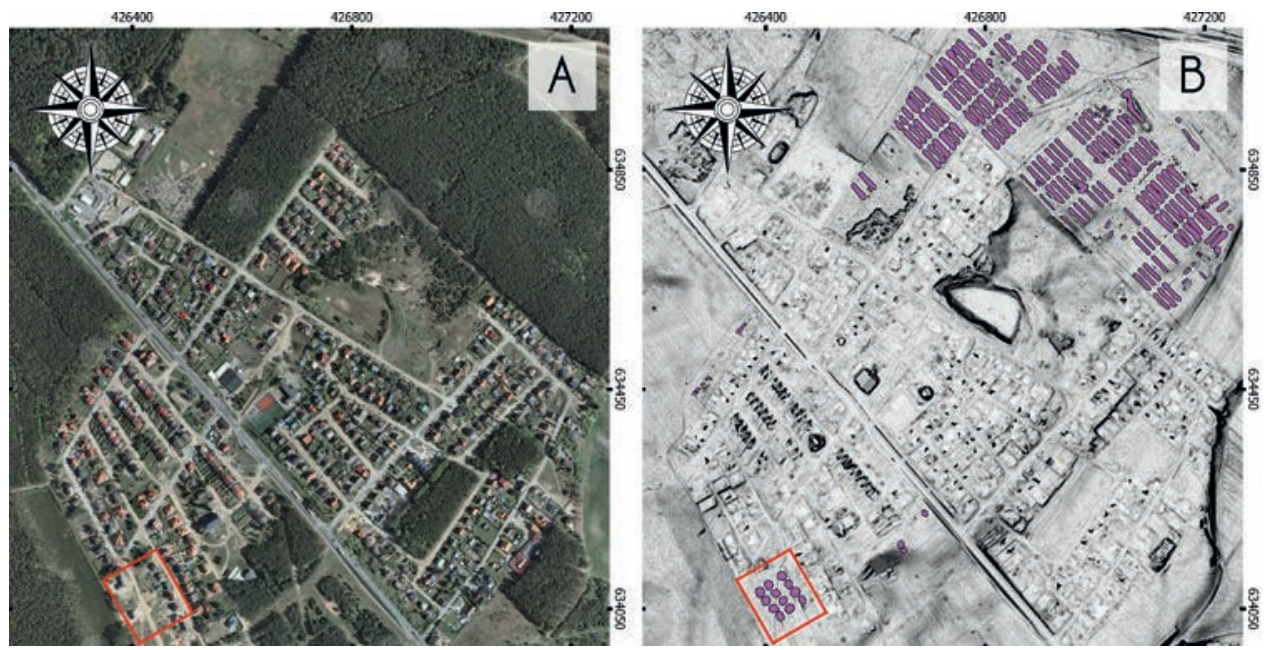

Ryc. 4. Teren obozu II w Tucholi. A - ortofotomapa ukazująca współczesną zabudowę obozu. B - interpretacja pochodnych lotniczego skanowania laserowego - na fioletowo oznaczono zarysy ziemianek obozowych (źródło CODGIK, oprac. Mikołaj Kostyrko). Obiekty w czerwonym kwadracie to relikty ziemianek zarejestrowane na zdjęciu lotniczym (oprac. Mikołaj Kostyrko)

Fig. 4. Camp II in Tuchola. A - orthophotomap showing the contemporary architecture of the camp. B interpretation of airborne laser scanning derivatives - the outlines of camp dugouts were marked in purple (source: CODGIK, prepared by Mikołaj Kostyrko). The structures in the red square are relics of dugouts registered in the aerial photograph (prepared by Mikołaj Kostyrko) 


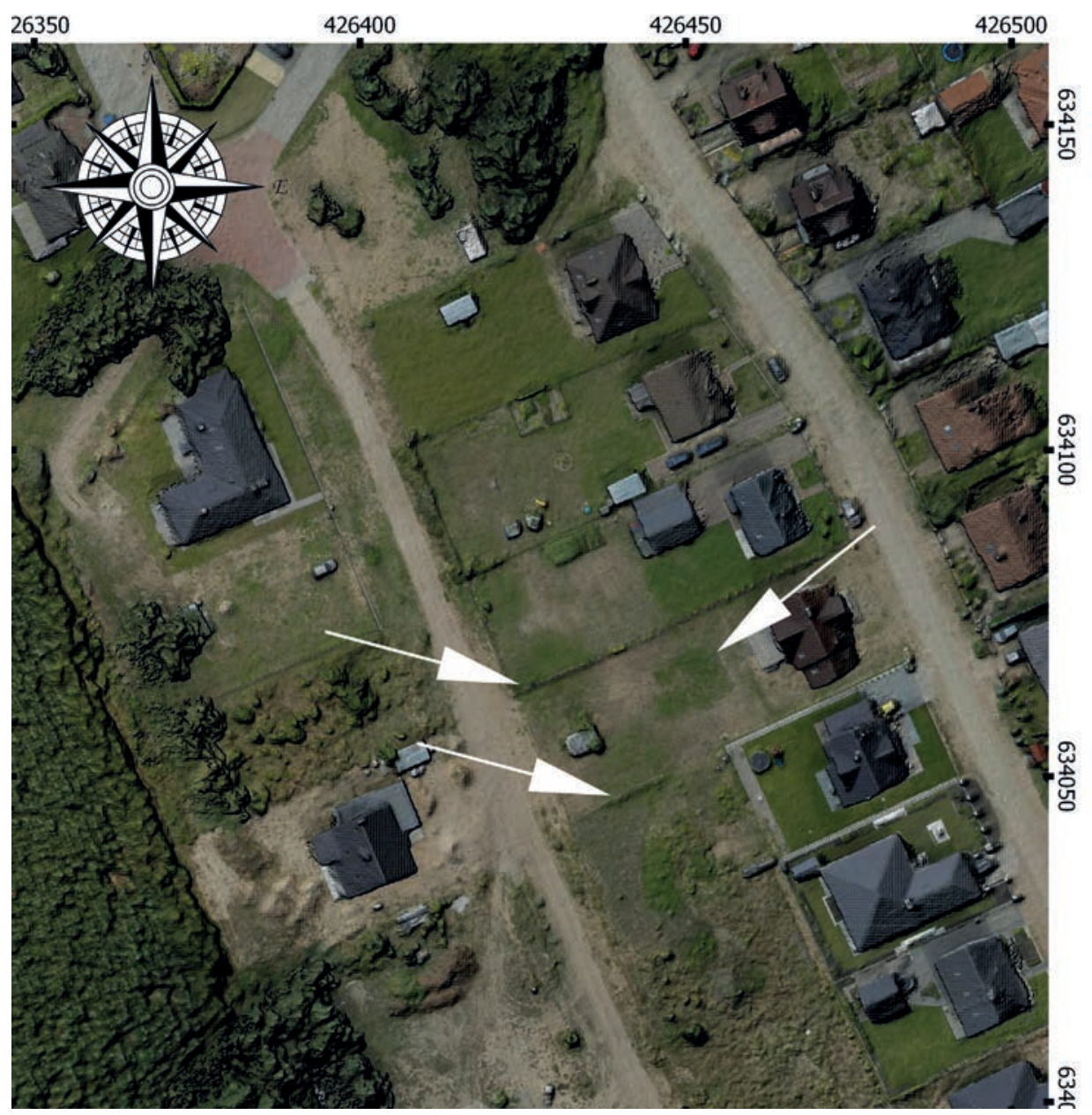

Ryc. 5. Integracja Numerycznego Modelu Terenu oraz ortofotomapy dla fragmentu obozu w Tucholi strzałki wskazują zarysy domniemanych ziemianek obozowych (oprac. Mikołaj Kostyrko)

Fig. 5. Integration of the Digital Elevation Model and orthophotomap for a fragment of the Tuchola camp - the arrows most likely indicate the outlines of the camp dugouts (prepared by Mikołaj Kostyrko)

Wykorzystanie metodyki badań etnograficznych w przypadku archeologicznych studiów nad reliktami niedawnej przeszłości jest niezbędnym wręcz elementem procesu badawczego. Na przykład Rodney Harrison i John Schofield (2009) argumentowali, że tego rodzaju badania są $\mathrm{w}$ istocie sposobem uprawiania etnografii. Tak ukierunkowaną archeologię określili mianem archeoetnografii (ang. archaeo-ethnography). W kontekście polskiej nauki szczególnie warte przywołania są działania Olgierda Ławrynowicza (np. 2013; Ławrynowicz, Badji, Majewski, 2017), który bada ślady zbrodni nazistowskich w podłódzkich lasach. Rzecz jasna elementem studiów 
są kwerendy archiwalne oraz badania wykopaliskowe. Równie pomocne są ustalenia poczynione $\mathrm{w}$ trakcie przeprowadzonych wywiadów etnograficznych, które potrafią uzupełniać, weryfikować, wzbogacać to, co jest znane z dokumentów archiwalnych i wyników archeologicznych prac weryfikacyjnych (por. Moshenska, 2007; Sturdy Colls, 2015). Podobne założenie poczyniono w trakcie śledzenia dziedzictwa obozu w Tucholi. Chodziło o możliwie szerokie uzupełnianie się źródeł materialnych, historycznych oraz informacji pozyskanych w trakcie rozmów z lokalną społecznością. W ten sposób niniejsze opracowanie argumentuje na rzecz uprawiania swego rodzaju - jakby to ujęli Harrison i Schofield (2009) - archeoetnografii również w kontekście dziedzictwa Wielkiej Wojny oraz walk polsko-bolszewickich.

Kolejne części pracy skupiają się na jednej kategorii pozostałości po obozie jeńców wojennych i internowanych w Tucholi. Tymi reliktami są różne manifestacje szeroko rozumianej kultury materialnej, która powstawała w trakcie trwania konfliktów zbrojnych lub też dla ich upamiętnienia. Tego rodzaju artefakty określa się w literaturze przedmiotu mianem sztuki okopowej. Druga część pracy sygnalizuje zatem problematykę sztuki okopowej. Z kolei ostatni rozdział artykułu omawia i prezentuje niewielki, ale zarazem wyjątkowy zbiór sztuki okopowej związanej z funkcjonowaniem obozów w Tucholi. Celem badań terenowych oraz niniejszej pracy było sondowanie następujących zagadnień: ile i co właściwie pozostało po miejscu przetrzymywania dziesiątek tysięcy ludzi między 1914 a 1923 rokiem oraz ile i co w istocie pozostało po osadzonych w tucholskim ośrodku?

\section{SZTUKA OKOPOWA POMIĘDZY PAMIĘCIĄ A ZAPOMNIENIEM}

W ramach realizacji celów projektu „Między pamięcią a zapomnieniem: archeologia a XX-wieczne dziedzictwo militarne na terenach zalesionych" badano różne kategorie śladów po I i II wojnie światowej. Na materialne pozostałości działań wojennych w lasach składały się m.in. relikty okopów, schronów drewniano-ziemnych, baraków, strzelnic i leje po wybuchach różnego rodzaju pocisków, a nawet inskrypcje pozostawione przez jeńców wojennych na drzewach (np. Kobiałka, 2017, 2019). Zarazem $\mathrm{w}$ wielu sytuacjach udało się zadokumentować kulturę materialną związaną z danym miejscem. Wśród artefaktów były m.in. puszki po konserwach, manierki, łuski od nabojów, drut kolczasty, cegły stanowiące element konstrukcyjny baraków, szkło apteczne itd. Jednak z wielu powodów najciekawsze $\mathrm{z}$ archeologicznego, historycznego i etnograficznego punktu widzenia okazały się relikty obozów jenieckich. Wymowny w tym miejscu jest przykład pierwszowojennego obozu w Czersku, w województwie pomorskim.

W trakcie weryfikacji terenowych badan archiwalnych, wizyt muzealnych, rozmów z lokalną społecznością udało się zadokumentować bogaty i różnorodny zbiór przedmiotów, które były wykonywane, przerabianie, personalizowane przez samych osadzonych (np. Kobiałka, 2018a, 2018b). Tego rodzaju kulturę materialną określa się zwykle mianem sztuki okopowej (ang. trench art). Problematyka sztuki okopowej 
jako takiej została już dobrze opisana (Saunders, 2000, 2003, 2010, 2016). Podobnie wygląda sytuacja z jej przykładami, które analizowano w ramach projektu „Między pamięcią a zapomnieniem..." (np. Kobiałka, 2018b). Na potrzeby niniejszej pracy należy podkreślić wyraźnie, że, zdaniem archeologa Nicholasa Saundersa (np. 2000, 2003, 2007), który już od ponad dwóch dekad zajmuje się tym problemem, za sztukę okopową należy uznać każdą rzecz wykonaną przez żołnierza, jeńca wojennego lub cywila $\mathrm{z}$ materiałów wojennych (np. wazony wykonywane $\mathrm{z}$ łusek od pocisków dużego kalibru, krucyfiksy zrobione z nabojów, zdobione papierośnice, popielniczki powstałe z granatów, ręcznie stworzone sztućce czy też grzebienie). Tego typu artefakty cieszyły się sporym zainteresowaniem już w trakcie trwania Wielkiej Wojny. Również obecnie są to przedmioty chętnie kolekcjonowane przez prywatne osoby albo jednostki muzealne. Co więcej, sztuka okopowa to nie po prostu artefakty, dzieła sztuki wykonane lub odnalezione w okopach. Przez to określenie należy rozumieć także każdy rodzaj kultury materialnej, który czasowo lub/i przestrzennie jest związany z działaniami militarnymi oraz ich późniejszymi konsekwencjami.

Wartość tego typu artefaktów zasadza się na fakcie, że są one odpowiedzią człowieka na wielowymiarowe, często także niedyskursywne doświadczenie walki, np. w okopach w Belgii, a także długie dni, tygodnie, miesiące i lata spędzone w niewoli za drutem kolczastym w obozie jenieckim w Prusach Zachodnich. Jak to trafnie ujął Saunders (2016, s. 27; tłumaczenie autora) w jednym z wielu opracowań na temat sztuki okopowej,

siłą sztuki okopowej jest to, że obejmuje ona totalność doświadczenia wojennego jako trójwymiarowy testament tych doświadczeń, jakiekolwiek by one nie były. Walczenie, zabijanie, bycie rannym, zbieranie i wymiana [pamiątek wojennych - dopisek D.K.], opracowywanie opowieści, konstruowanie tożsamości i dbanie o własną reputację są wszystkie aspektami konfliktu. Sztuka okopowa jest fizyczną manifestacją wojny i w swojej ilości oraz różnorodności pierwszowojenna sztuka okopowa reprezentuje ludzkie odpowiedzi wobec intensywności oraz presji cierpienia i przetrwania, których wiele jednostek i rodzin doświadczyło pomiędzy 1914 a 1918 rokiem, i przez wiele następnych dekad. Dzisiaj wojna jest skończona i ludzie dawno odeszli, lecz przedmioty pozostają, ponownie będąc docenionymi i postrzeganymi jako kotwice pamięci i tożsamości.

Z powyższego jasno wynika, że sztuka okopowa nie jest zwykle dziełem sztuki. Jej wartość estetyczna również jest w wielu wypadkach dyskusyjna. Bliżej jej zwykle - używając języka etnologicznego - do sztuki naiwnej (Bihalji-Merin, Tomasević, 1984). W rzeczy samej większość uczestników działań wielkowojennych stanowili chłopi, którzy zostali siłą wciągnięci w wir zawieruchy wojennej. Stąd też te liczne, często proste i raczej banalne przedmioty wykonane z materiałów wojennych - użytkowe lub też upamiętniające konflikt - są w rzeczywistości materializacją jednostkowych, pojedynczych doświadczeń wojennych i emocji. Dokładnie ten kontekst czyni owe artefakty tak interesującym materiałem do studiów historycznych, archeologicznych, etnologicznych nad tym, jak kultura materialna była wykorzystywana w trakcie konfliktu zbrojnego. Sztuka okopowa dotyka i upamiętnia pojedynczego człowieka, 
zwykle szeregowego uczestnika wojen światowych. Przez długie dekady te aspekty działań militarnych umykały opracowaniom historycznym.

Co więcej, także sama problematyka sztuki okopowej nie interesowała bliżej archeologów, historyków i antropologów. Dopiero na przestrzeni ostatnich dwóch dekad podjęto próby jej systematyzacji. Impulsem były studia Saundersa (np. 2000, 2003), który w kreatywny sposób połączył archeologiczne zainteresowanie kulturą materialną, wrażliwość wobec faktów historycznych oraz etnologiczny nacisk na wartość słowa mówionego i współczesne znaczenia analizowanych przykładów sztuki okopowej. W polskiej archeologii, historiografii i etnologii w istocie brakuje jeszcze wyczerpujących opracowań na ten temat (por. Hubacz, 2017, 2018; Kobiałka, 2018a, 2018b). Badania związane z dziedzictwem tucholskiego obozu pozwoliły na dokumentację i opis kolejnych przykładów sztuki okopowej.

Podsumowując, przykłady sztuki okopowej można rozumieć jako przedmioty pamięci, artefakty materializujące ludzką pamięć w czasie wojny i o życiu codziennym w trakcie konfliktu zbrojnego (por. także Nora, Kritzman, 1996). Potwierdzeniem tej obserwacji są przedmioty związane z Tucholą, które można określić jako sztukę okopową. Wstępne zasygnalizowanie tego zagadnienia stanowi temat ostatniej części artykułu.

\section{STUDIUM PRZYPADKU: SZTUKA OKOPOWA ZWIĄZANA Z OBOZEM JEŃCÓW WOJENNYCH I INTERNOWANYCH W TUCHOLI}

Informacje dotyczące sztuki okopowej związanej z obozem w Tucholi pochodzą z trzech rodzajów badań. Były to materiały pozyskane przez analizę dokumentów historycznych, archeologicznych weryfikacji terenowych oraz wywiadów etnograficznych. Zadokumentowane w ten sposób nieliczne przykłady sztuki okopowej uzupełniają się i pokazują różne wymiary wykorzystywania i przetwarzania kultury materialnej w trakcie konfliktu zbrojnego oraz jego późniejszych konsekwencji (por. Carr, Mytum, 2012; Mytum, Carr, 2013).

Już w 1915 roku Herman Montanus wydał pracę Die Kriegsgefangenen in Deutschland. Gegen 250 Wirklichkeitsaufnahmen aus deutschen Gefangenenlagern mit einer Erläuterung. Była to publikacja o głębokim wydźwięku propagandowym. Omawiała i dokumentowała rzekomo doskonałe warunki życia jeńców pojmanych przez wojska Cesarstwa Niemieckiego w pierwszych miesiącach trwania Wielkiej Wojny. W pracy pojawiają się nawet fragmenty listów żołnierzy francuskich i brytyjskich, w których prosili rzekomo swoje rodziny, żeby już nie przysyłały im paczek z żywnością, bo tak dobrze jak w obozie, to nigdy wcześniej nie byli karmieni. Książka jest bogato ilustrowana. Dwa zdjęcia wykonano także w Tucholi. Rycina 40 znajdująca się na stronie 41 pracy Montanusa jest szczególnie interesująca (ryc. 6). Przedstawia grupę rosyjskich jeńców stojących przed wejściem do obozowej ziemianki. Budynek został jednak starannie przyozdobiony. 


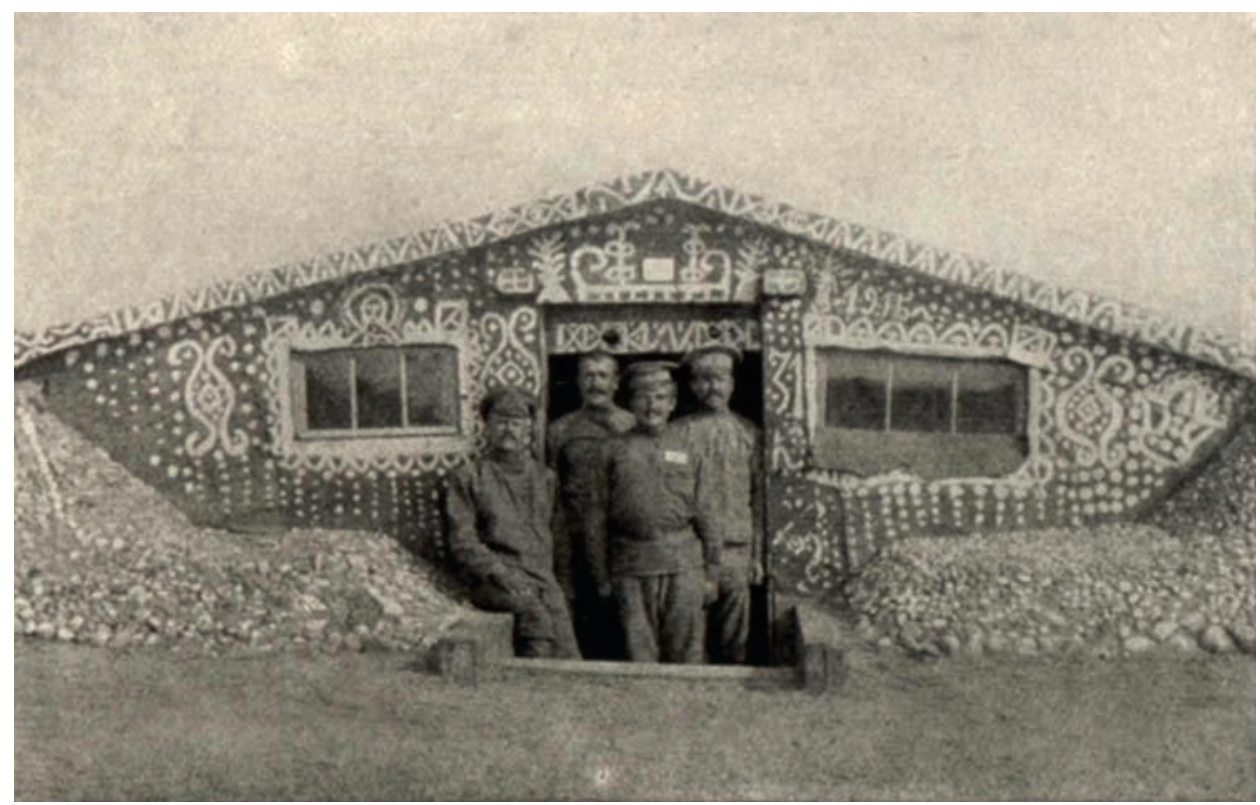

Ryc. 6. Zdobiona ziemianka z terenu obozu jenieckiego w Tucholi wraz z czterema rosyjskimi jeńcami przed wejściem do budynku (za: Montanus, 1915, ryc. 40, s. 41)

Fig. 6. Decorated dugout from the camp in Tuchola with four Russian prisoners of war in front of the entrance to the building (after: Montanus, 1915, ryc. 40, s. 41)

Tego typu praktyki, jak malowanie, zdobienie miejsc, w których siłą przetrzymywano żołnierzy, można rozumieć jako sposób udamawiania obcej przestrzeni. Malowanie ścian budynków było powszechnie stosowaną praktyką na wsi na przełomie XIX i XX wieku w wielu rejonach Europy, włączając w to ogromne połacie Imperium Rosyjskiego (np. Benedyktowicz, Benedyktowicz, 1992). W ten sposób rosyjscy jeńcy, na podstawie osobistych wspomnień z rodzinnych stron, starali się odwzorować elementy ich domowego krajobrazu kulturowego - to, co obce, stawało się przynajmniej w niewielkim stopniu swojskie. Odniesienia do czasów przed danym konfliktem zbrojnym są jednym z typowych aspektów sztuki okopowej. Pomalowana, udekorowana przez tucholskich jeńców ziemianka, w której mieszkali, to nic innego jak właśnie jedna z manifestacji sztuki okopowej. Definicja obejmuje różne formy kultury materialnej. Są nią także budynki przyozdobione przez osadzonych. Sztuką okopową są także pomniki.

Jedynym monumentem upamiętniającym zmarłych jeńców w Tucholi w trakcie trwania Wielkiej Wojny jest pomnik na obozowym cmentarzu. Jego wykonawcami było trzech Polaków, którzy służyli w carskiej armii - Ciebel, Markowski i Paschkewitsch (ryc. 7). Odsłonięcie pomnika miało miejsce 18 listopada 1917 roku. Ma kształt prostokątnego monumentu zwieńczonego granitowym krzyżem maltańskim. Na każdej 

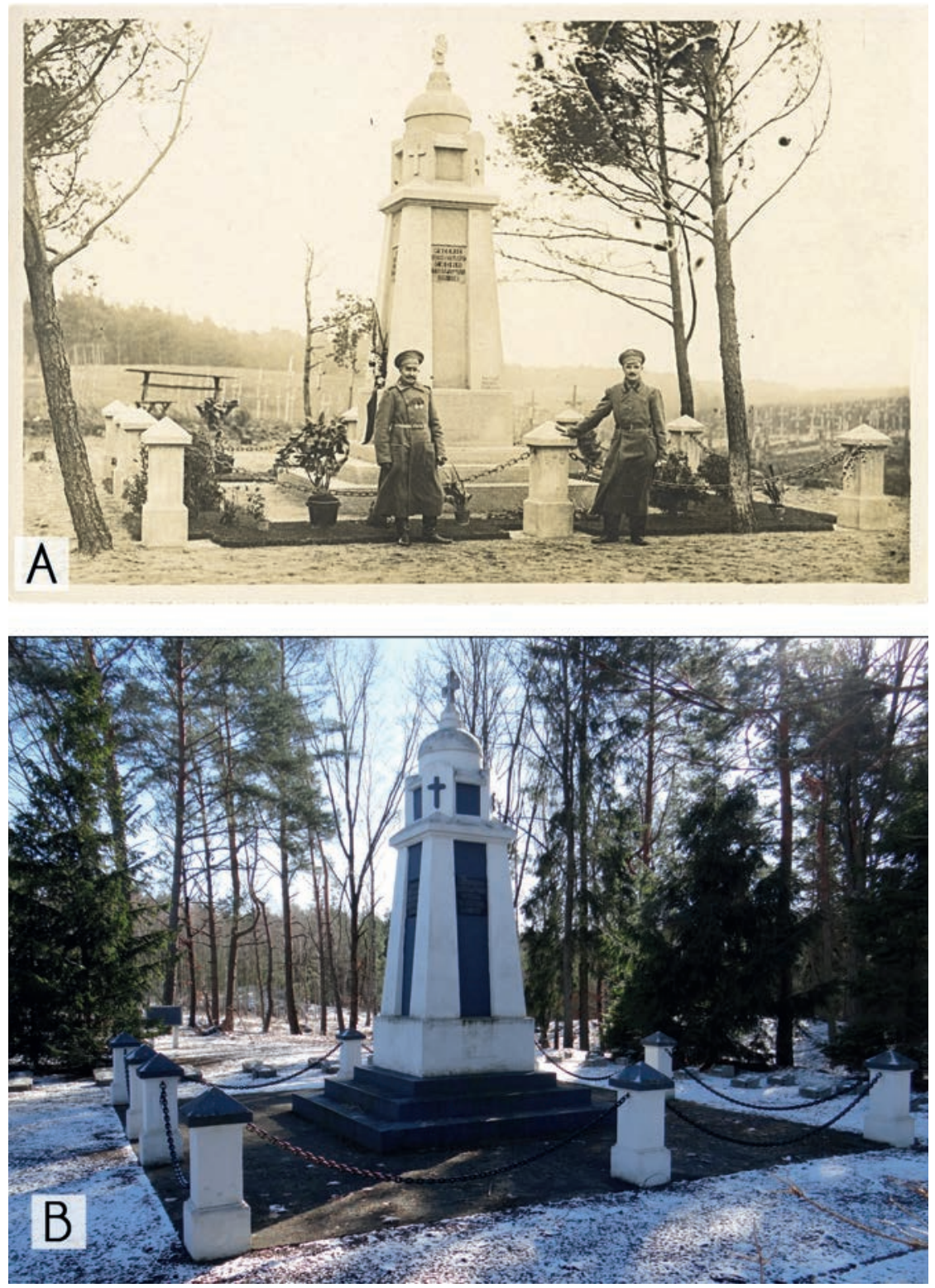

Ryc. 7. Najlepiej znany fragment obozu w Tucholi, który przetrwał do współczesności - cmentarz jeńców wojennych. A - fotografia ukazująca dwóch żołnierzy rosyjskich przed pomnikiem na cmentarzu jenieckim w Tucholi (zbiory prywatne Zenona Wędzickiego). B - stan pomnika na 2019 rok (fot. Dawid Kobiałka)

Fig. 7. Material and best-known fragment of the Tuchola camp that has preserved until the present - a prisoner of war cemetery. A - a photograph of two Russian soldiers in front of a monument erected at the cemetery (Zenon Wędzicki's private collection). B - the state of preservation of the monument in 2019 (photo by Dawid Kobiałka) 
ze stron znajduje się tablica pamiątkowa w języku rosyjskim (tłum. Rosyjscy jeńcy wojenni swoim towarzyszom), rumuńskim (tłum. Rumuńscy jeńcy wojenni swoim kamratom), polskim (Wojenni jeńcy Polacy swoim Towarzyszom 1914-1918) i niemieckim (thum. Rosyjscy i rumuńscy jeńcy wojenni swoim towarzyszom). Monument podkreśla wielowyznaniowość poległych żołnierzy. W górnych narożnikach pomnika umieszczono wyobrażenia krzyża łacińskiego oraz prawosławnego, gwiazdy Dawida i półksiężyca wraz z gwiazdą. Całość założenia ogrodzona jest rzędem betonowych słupków połączonych metalowym łańcuchem. Pomnik jako forma materialnego upamiętnienia żołnierzy zmarłych w trakcie Wielkiej Wojny w Tucholi to przykład - jak powiedzieliby niektórzy (np. Saunders, 2010) - materialnej pamięci o czasach pierwszej światowej pożogi. To zarazem monumentalny przykład sztuki okopowej.

Zupełnie odmiennym przykładem jenieckiej kreatywności za drutem kolczastym w Tucholi jest fragment niewielkiego przedmiotu, który zarejestrowano w trakcie dokumentacji stanu zachowania ziemianek obozowych (por. ryc. 3). Został wycięty z kawałka blachy aluminiowej (ryc. 8). Od strony wewnętrznej jego krawędzie schodzą się, tworząc kąt prosty. Zachowany fragment został pokryty rytami. Ma wymiar 2x2,5 cm. Najprawdopodobniej jest to element ręcznie wykonanej ramki do zdjęcia. Mógł obramowywać niewielką fotografię przedstawiającą zapewne kogoś bliskiego dla jednego z wielu bezimiennych jeńców wojennych z Tucholi, np. żonę czy też dziecko/dzieci żołnierza. Wiadomo z wielu przykładów, że zdjęcia bliskich były przedmiotami wręcz bezcennymi dla jeńców w trakcie długich lat spędzonych w niewoli (por. Carr, Mytum, 2012). Stąd szczególnie o nie dbano - w tym przypadku ręcznie wykonano obramowanie $\mathrm{z}$ kawałka blaszki aluminiowej, dodatkowo pokrywając zdobieniami. Jeniec mógł wykorzystać fragment swojego wyposażenia (np. aluminiową menażkę) lub też nabył gotowy artefakt od obozowego rzemieślnika. Rzecz jasna okoliczności powstania przedmiotu mogło być wiele. Jest to jednak kolejny przykład tego, jak jeńcy tworzyli, przetwarzali kulturę materialną, która miała służyć utrzymaniu kontaktu z czasami sprzed niewoli. Kultura materialna pełniła często formę pomostu łączącego przeszłość i współczesność osadzonych.
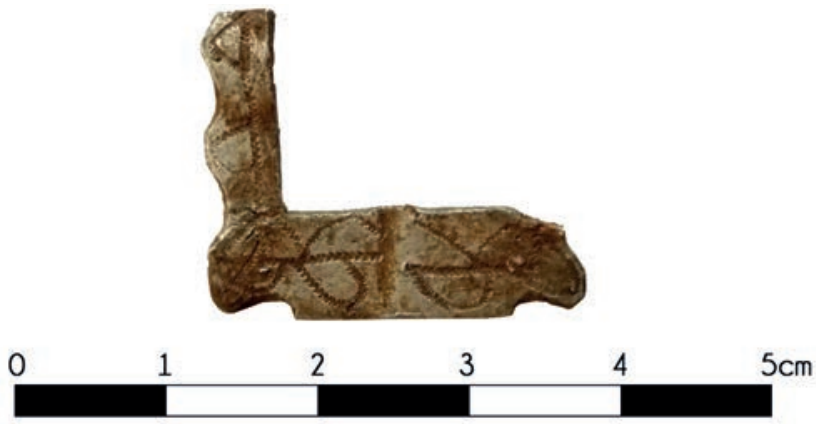

Ryc. 8. Zdobiony fragment aluminiowej blaszki, który został przetworzony na ramkę do zdjęcia (fot. Dawid Kobiałka)

Fig. 8. Decorated fragment of an aluminum's plague which was reused as photo frame (photo by Dawid Kobiałka) 
Dokumenty historyczne raczej zdawkowo wspominają o przykładach sztuki okopowej. W przypadku Tucholi było to jedno zdjęcie z pracy Montanusa. Fakt, że rozpoznanie archeologiczne miało charakter nieinwazyjny, wyraźnie ograniczył możliwości dokumentacji wielości i różnorodności tucholskiej sztuki okopowej, którą z pewnością można byłoby odkryć w trakcie prac wykopaliskowych. Z tych też powodów najważniejsze dla dalszego wywodu okazały się badania etnologiczne. W ich trakcie rejestrowano kolejne różnorodne manifestacje przedmiotów, które należy określić mianem sztuki okopowej.

Jednym z najważniejszych informatorów w trakcie badania dziedzictwa tucholskiego obozu był Zenon Wędzicki, regionalista, miłośnik ziemi tucholskiej i kolekcjoner. W kontekście badań nad Tucholą kluczowe znaczenie miało to, że Wędzicki zbiera m.in. pocztówki i zdjęcia związane z obozem oraz kolekcjonuje tucholskie fenigi - specjalne monety, za które jeńcy mogli kupować różnego rodzaju towary w obozowej kantynie. Zwykle pocztówki propagandowe są powielonymi zdjęciami wykonanymi w poszczególnych strefach obozowych (ryc. 1). Niemniej w analizowanej kolekcji znajdują się m.in. trzy bardzo ciekawe eksponaty (ryc. 9). Jedna z pocztówek jest ręcznie wykonanym rysunkiem, który następnie pomalowano, ukazującym rosyjskiego jeńca (ryc. 9a). Kolory zachowały się do chwili obecnej: trawa i ziemia mają kolor brązowy, szynel jest w odcieniach szarości i brązu, torba i czapka sa zielone, przymocowany do brązowego paska czarny przedmiot to żołnierski kubek. Jeniec otulony jest ciemnobrązowym szalem. Pocztówka z ryciny 9b została wykonana w podobny sposób. Odręczny rysunek, który następnie został skopiowany, przedstawia dwóch rosyjskich więźniów. W końcu wartościową manifestacją żołnierskiej kreatywności jest pocztówka zrobiona z wyprasowanego prostokątnego kawałka kory brzozowej (ryc. 9c). Idąc tropem definicji sztuki okopowej Saundersa, także trzy wyżej opisane artefakty/dokumenty są przykładem kultury materialnej wykonanej przez żołnierzy i jeńców wojennych w trakcie trwania konfliktu zbrojnego - w tym przypadku Wielkiej Wojny.

Obóz jeniecki to nie tylko jeńcy wojenni, ale również żołnierze, których zadaniem było pilnowanie w nim porządku. Po nich także pozostały w Tucholi całkiem liczne ślady. Częścią badań antropologicznych była rozmowa z Jerzym Szwankowskim, który opisuje historię Tucholi w licznych publikacjach naukowych (np. Szwankowski, 2010). Regionalista pokazuje jeszcze inną twarz dziedzictwa obozowego. Okazuje się bowiem, że dziadek jego żony był tu wachmanem (strażnikiem) podczas I wojny światowej. W rodzinie zachowały się wspomnienia dotyczące dziadka, a także przedstawiające go zdjęcia. Ponadto do chwili obecnej przetrwały niektóre z jego osobistych przedmiotów (ryc. 10). Do najciekawszych niewątpliwie należy zaliczyć ręcznie wykonaną broszkę, która powstała z dwóch srebrnych monet (10 kopiejek) wybitych w 1913 oraz 1914 roku (por. także: Łopatyńska, Szelągowska, 2017, s. 44). Monety zostały połączone ze sobą aluminiowym łącznikiem przedstawiającym armatę. Każda z nich ma także dolutowane aluminiowe ucho. Uszka łączy łańcuszek. Rewers jednej z monet został wykorzystany do przymocowania formy zawiasu, na którym opiera się igła ozdoby. Druga ma przylutowane uszko, w które wpinano igłę. 


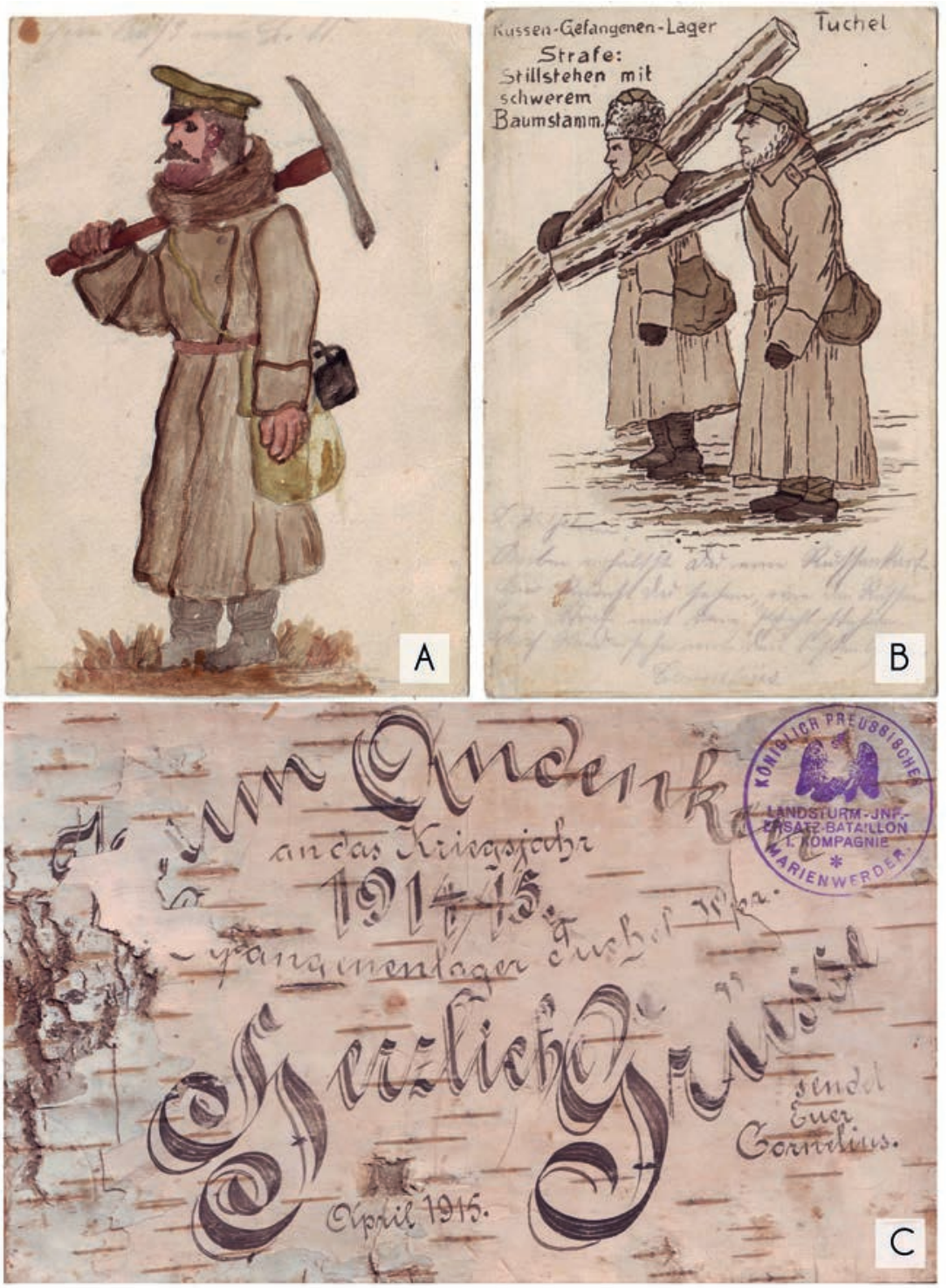

Ryc. 9. Przykłady pocztówek związanych z obozem w Tucholi. A - ręcznie wykonana i pomalowana pocztówka prezentującego rosyjskiego jeńca z kilofem na barku (zbiory prywatne Zenona Wędzickiego). B - ręcznie wykonana, a następnie skopiowana pocztówka z dwójką rosyjskich jeńców wojennych (zbiory prywatne Zenona Wędzickiego).

$\mathrm{C}$ - pocztówka wykonana z kory brzozy (zbiory prywatne Zenona Wędzickiego)

Fig. 9. Examples of postcards related to the Tuchola camp. A - hand-made and painted postcard presenting a Russian prisoner of war with pickaxe (Zenon Wędzicki's private collection). B - hand-made and later copied a postcard presenting two Russian prisoners of war (Zenon Wędzicki's private collection). C - a postcard made of birch bark (Zenon 
Artefakt można interpretować na dwa sposoby. $Z$ jednej strony mogła to być ręczna robota jeńca $\mathrm{z}$ obozu w Tucholi, którą, zapewne w trakcie obozowej wymiany, nabył dziadek żony rozmówcy. Z drugiej - nie można wykluczyć, że przedmiot, choć wykonany z rosyjskich monet, powstał poza obozem. Ręczne tworzenie, przetwarzanie artefaktów i ich fragmentów przez jeńców wojennych oraz ludność cywilną w trakcie I wojny światowej jest powszechnie znane w literaturze przedmiotu (więcej w: Saunders, 2010; Kobiałka, 2018b).

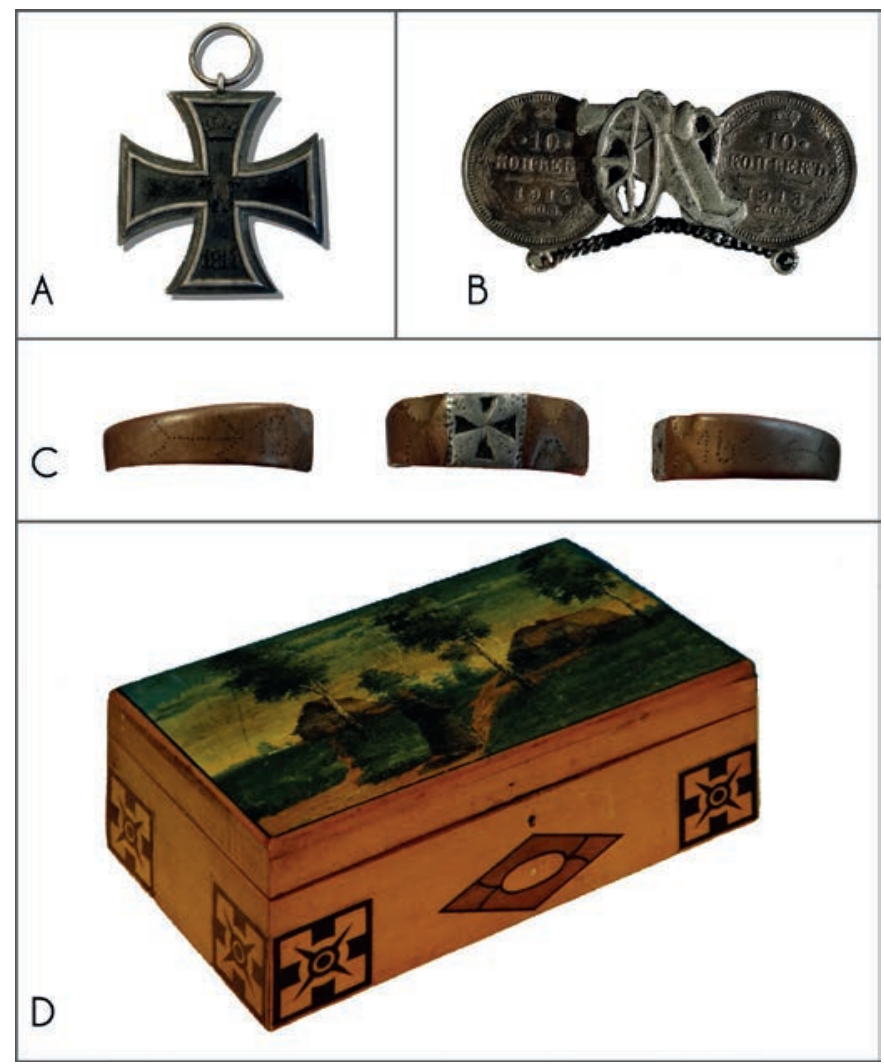

Ryc. 10. Materialne pozostałości po obozie w Tucholi. A - krzyż żelazny II kategorii z czasów I wojny światowej należący do dziadka żony rozmówcy, który był strażnikiem w obozie w Tucholi (fot. Dawid Kobiałka). B - ręcznie wykonana zapinka $z$ dwóch połączonych ze sobą srebrnych monet o nominale 10 kopiejek z 1913 i 1914 roku - przykład sztuki okopowej (fot. Dawid Kobiałka). C - ręcznie wykonany tzw. sygnet patriotyczny - przykład sztuki okopowej (fot. Dawid Kobiałka). D - drewniana skrzynka wykonana przez jeńca z Tucholi - przykład sztuki okopowej (fot. Dawid Kobiałka)

Fig. 10. Material remains of the Tuchola camp. A - the Iron Cross 2 (II category) that was obtained by a guard who served in the Tuchola camp (photo by Dawid Kobiałka). B - hand-made brooch of two 10 kopek coins - an example of trench art (photo by Dawid Kobiałka). $\mathrm{C}$ - hand-made so-called patriotic ring - an example of trench art (photo by Dawid Kobiałka). D - a wooden casket made by a prisoner of war in Tuchola - an example of trench art (photo by Dawid Kobiałka) 
Drugi eksponat zachowany w rodzinie Szwankowskiego jest zarazem kolejnym przykładem sztuki okopowej. To tzw. sygnet patriotyczny - ręcznie wykonany pierścień z kawałka blachy mosiężnej. W centralnej części ma nakładkę aluminiową z wyrytym na powierzchni krzyżem, a jego wnętrze pokryto czarnym barwnikiem. Krzyż okala rząd kropek, które schodzą się do jego centralnego punktu. Boczne powierzchnie także są pokryte zdobieniami. Z lewej strony widać strzałkę i liczbę 19, z prawej natomiast 16 oraz kolejną strzałkę. Liczby 19 i 16 oznaczają najprawdopodobniej datę powstania sygnetu - rok 1916. Tego rodzaju kultura materialna była często tworzona przez jeńców wojennych jako towar na wymianę z niemieckimi strażnikami obozów lub też pamiątki, dzięki którym więźniowie wkupywali się w łaski pilnujących. Światło na tę praktykę rzucają między innymi wspomnienia francuskiego żołnierza Étienne'a Houarda, który był osadzony w obozie w Pile w czasie I wojny światowej:

W wolnym czasie, który mieliśmy po pracy, Bizet [kolega Houarda - dopisek D.K.] robił pierścionki z aluminium. Były one podobne do małych obręczy, obdarował nimi każdego strażnika. Diabelski strażnik dowiedział się o producencie i także chciał dostać taki pierścionek. Kiedy zobaczył, że jest nim Bizet, złagodniał nieco w stosunku do niego i poprosił go o jeden taki pierścionek. Bizet nie miał żadnego gotowego, strażnik kazał mu więc zostać cały dzień, by go zrobić. Bizet przyłożył się bardzo i tak oto wszystko wróciło do normy. (Bączyk i in., 2018, s. 111)

Sygnety patriotyczne w trakcie I wojny światowej były także wykonywane przez ludność cywilną i wyspecjalizowane warsztaty jubilerskie (Ł. J. Hubacz, informacja ustna 4.03.2019). Ostatnim przedmiotem wykonanym przez jeńca z obozu w Tucholi, jak przyznał Szwankowski w trakcie rozmowy, jest niewielka, starannie wykonana drewniana szkatułka, której wieko zdobi namalowany pejzaż wiejski (por. także: Kobiałka, 2018b).

Jeszcze mniej śladów i wspomnień przetrwało do współczesności po jeńcach bolszewickich oraz Rosjanach, Ukraińcach internowanych w Tucholi. Jednym z przetrzymywanych tam oficerów generała Stanisława Bułak-Bałachowicza był Paweł Ismajłowicz. Pamięć i materialne pamiątki z nim związane zachowały się w rodzinie Marii Ollick. Z przeprowadzonej rozmowy wynika, że jej dziadek Wojciech Pryll opiekował się uwięzionymi oficerami. Ismajłowicz, z wykształcenia lekarz, pracował poza obozem. Wydawał sprzęt osobom, które uprawiały tenis ziemny na miejscowych kortach. Pryll jeździł po Ismajłowicza do obozu, zabierał go do pracy, a po południu odwoził z powrotem. Między mężczyznami musiała zawiązać się bliższa znajomość, ponieważ Rosjanin bywał w odwiedzinach u państwa Pryllów. Co więcej, jak przyznała Maria Ollick (informacja ustna, 20.02.2019), w rodzinie krążyła opowieść, według której Ismajłowicz miał podkochiwać się w małżonce Wojciecha Prylla - Helenie. To właśnie w domu Pryllów internowany zapoznał się z dziełem Władysława Bandurskiego (1910) Jadwiga. Święta królowa na polskim tronie. Opowieść dziejowa $w$ trzech tomach. Książka zawierała m.in. 11 kolorowych rycin przedstawiających różne epizody z życia królowej Jadwigi. Ich autorem był Piotr Stachiewicz, krakowski artysta malarz (ryc. 11). 


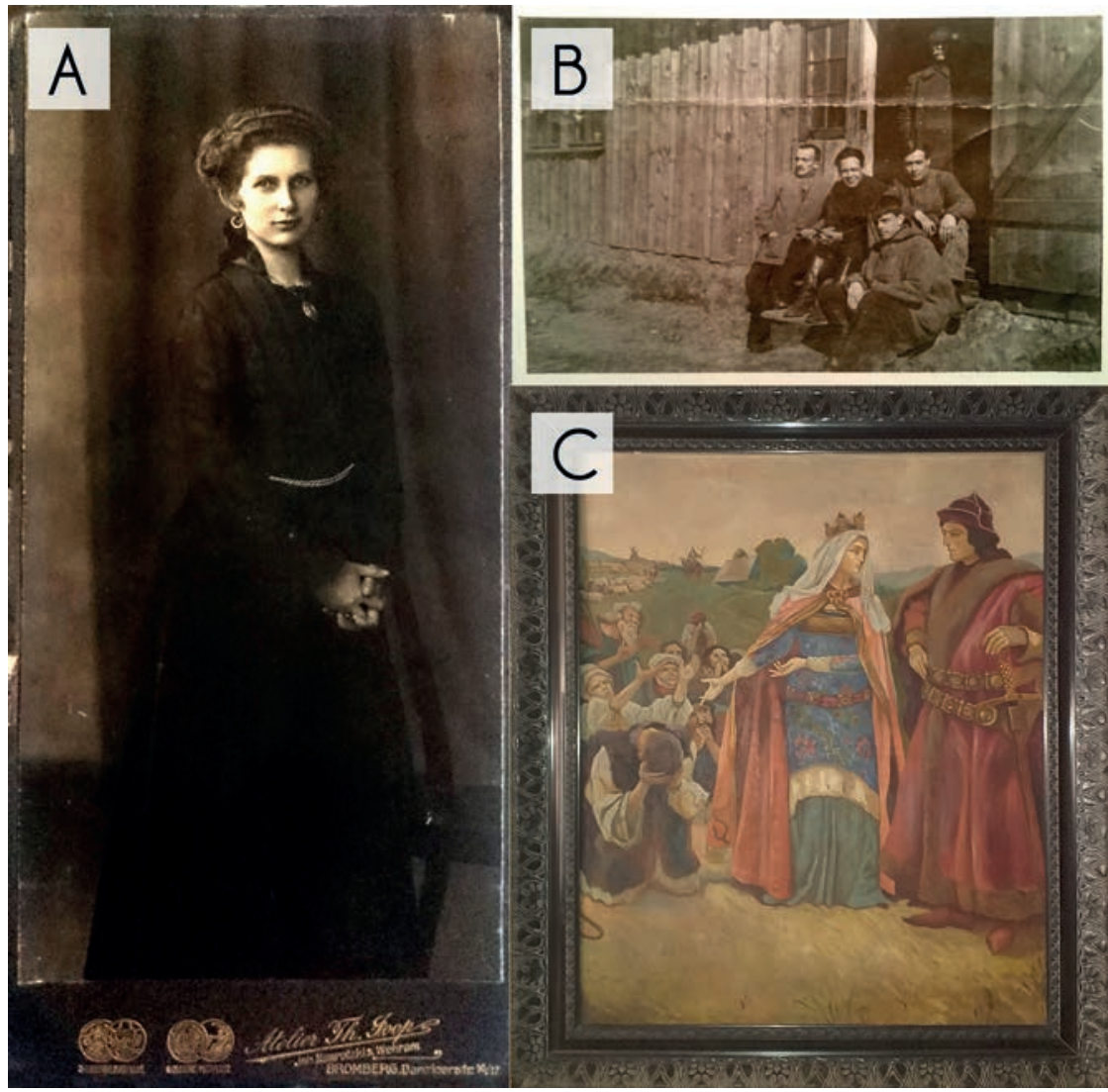

Ryc. 11. A - Helena Pryll - babcia Marii Ollick. To właśnie w niej miał się podkochiwać internowany Paweł Ismajłowicz (zbiory prywatne Marii Ollick). B - zdjęcie wykonane na terenie obozu w Tucholi w 1921 roku - w tle stoi jeden z obozowych baraków. Wykonany ołówkiem krzyżyk nad głową pierwszego mężczyzny od lewej oznacza Ismajłowicza (zbiory prywatne Marii Ollick). C - obraz namalowany przez Ismajłowicza dla dziadków Marii Ollick (fot. Dawid Kobiałka)

Fig. 11. Helena Pryll - a grandmother of Maria Ollick, one of the respondents during the research (Maria Ollick's private collection). According to family stories, Paweł Ismajlowicz, one of the Tuchola prisoners, was in love with her. B - a photograph taken at the Tuchola camp in 1921. A cross made of pencil over the head of one of the prisoners indicates Ismajlowicz (Maria Ollick's private collection). C - a painting drawn by Ismajlowicz for grandparents of Maria Ollick (photo by Dawid Kobiałka)

Ismajłowicz na podstawie rycin z książki Bandurskiego wykonał przynajmniej dwa obrazy, które zostały podarowane Pryllom. Jak się okazało, był sprawnym malarzem, kopistą amatorem. Jeden przedstawia Jadwigę i Władysława Jagiełłę wśród ubogich, drugi z obrazów był sceną ukazującą chrzest Litwy. Ismajłowicz po ostatecznym zamknięciu obozu w styczniu 1923 roku wrócił do ojczyzny. Jeden z tych obrazów Maria 
Ollick dostała w posagu. Drugi był w posiadaniu siostry matki respondentki. Niestety tę cenną pamiątkę sprzedano. Natomiast zachowany obraz wisi obecnie w mieszkaniu państwa Marii i Jerzego Ollicków w Tucholi i jest ważnym elementem rodzinnej historii. Należy w tym miejscu podkreślić, że reprodukcja ryciny z książki Bandurskiego, którą wykonał Ismajłowicz, jest przykładem sztuki okopowej. Wartości temu artefaktowi dodaje to, że w literaturze przedmiotu właściwie nie są znane inne przykłady tak datowanej sztuki okopowej związanej z etapem internowania Rosjan i Ukraińców między 1921 a 1923 rokiem w Polsce. Pamiątki rodzinne mogą więc być wartościowymi śladami niedawnej przeszłości - przedmiotami wartymi archeologicznej i etnograficznej uwagi. W tego rodzaju artefaktach problematyka badań archeologicznych, zagadnienia sztuki i kwestie pamięci przenikają się na wielu poziomach.

\section{PODSUMOWANIE}

Jak pokazuje to już wiele studiów przypadków, archeologiczne badania nad dziedzictwem niedawnej przeszłości nie są po prostu dopowiadaniem tego, co już doskonale wiadomo z dokumentów pisanych (Kostyrko, 2018). Źródła historyczne, archeologiczne (materialne), etnograficzne bardzo często wzajemnie się wzbogacają, weryfikują, dopełniają (np. Sturdy Colls, 2015). Tak też wyglądała sytuacja w kontekście badań nad reliktami obozu jeńców wojennych i internowanych w Tucholi (por. Kobiałka i in., 2016, 2017).

Niniejszy artykuł sygnalizował różne wymiary dziedzictwa obozowego. Najpierw omawiał wstępne wyniki badań nieinwazyjnych, które pozwoliły zadokumentować ponad 200 reliktów obozowych. Ważną ich składową były także wywiady etnograficzne, których celem było oszacowanie, czy i ile właściwie pozostało po obozie, jego jeńcach i strażnikach wśród lokalnej społeczności. W ich trakcie zadokumentowano niewielki zbiór opowieści, dokumentów, pamiątek rodzinnych, w których w różny sposób obóz był obecny. Na podstawie rozmów z respondentami, a także wyjazdów terenowych udało się zarejestrować różne przedmioty, które zostały wykonane, przerobione przez osadzonych w Tucholi lub też są formą ich materialnego upamiętnienia. Tego rodzaju kultura materialna ma bardzo precyzyjną definicję $\mathrm{w}$ dyskursie archeologicznym - każdy taki artefakt jest materializacją sztuki okopowej. $Z$ tego powodu jedna z części artykułu pobieżnie sygnalizowała zagadnienie sztuki okopowej. Ostatni, zasadniczy rozdział pracy to omówienie kilku manifestacji sztuki okopowej, która jest związana z obozem jeńców wojennych i internowanych w Tucholi.

Sztuka okopowa to w rzeczywistości zagadnienie, gdzie materia, problematyka pamięci i wytwórczości artystycznej w czasach wojny, niewoli nachodzą na siebie. To doskonały poligon doświadczalny do śledzenia jednostkowego, indywidualnego doświadczenia wojennego. Wartość omawianych artefaktów polega także na tym, że problematyka sztuki okopowej do tej pory była poza zasadniczym polem badań w ramach archeologii współczesności w Polsce. Prezentowane artefakty, dokumenty oraz historie, które za nimi stoją, pojawiają się po raz pierwszy w obiegu naukowym. 


\section{PODZIĘKOWANIA}

Wiele osób pomogło mi w różny sposób w trakcie badań. Byli to m.in. Mikołaj Kostyrko i Kornelia Kajda, z którymi rozpocząłem poszukiwania materialnych śladów po obozie w Tucholi. Lokalni miłośnicy historii Tucholi również podzielili się ze mną swoimi zbiorami, informacjami i wspomnieniami. Byli to: Zenon Wędzicki, Jerzy Szwankowski, Paweł Redlarski, Filip Wegner, Maria i Jerzy Ollickowie oraz Adam Stefan Krupa. Moja żona przygotowała ryciny do tekstu.

Badania są częścią projektu finansowanego ze środków Narodowego Centrum Nauki przyznanych na podstawie decyzji numer DEC-2016/20/S/HS3/00001.

\section{BIBLIOGRAFIA}

Bandurski, W.

1910 Jadwiga. Święta królowa na polskim tronie. Opowieść dziejowa w trzech tomach. Bytom: Katolik.

Bączyk, J., Kaczmarek, M., Usurski, M.

2018 Obóz jeniecki w Pile 1914-1919. Wspomnienia jeńców. Piła: Muzeum Stanisława Staszica w Pile.

Benedyktowicz, D., Benedyktowicz, Z.

1992 Dom w tradycji ludowej. Wrocław: Wiedza o Kulturze.

Bihalji-Merin, O., Tomasević, N.-B. (red.)

1984 World Encyclopedia of Nä̈ve Art: A Hundred Years of Nä̈ve Art. London: F. Muller.

Carr, G., Mytum, H. (red.)

2012 Cultural Heritage and Prisoners of War: Creativity behind Barbed Wire. New York: Routledge.

Harrison, R., Schofield, J.

2009 Archeo-ethonography, Auto-archaeology: Introducing Archaeologies of the Contemporary Past. Archaeologies, 5(2), 185-209.

Hubacz, Ł. J.

2017 Manierki jeńców wojennych 1914-1918 na tle manierek państw zaborczych / Canteens of Prisoners of War 1914-1918 Compared with the Ones of Occupants. Mińsk Mazowiecki: Muzeum Ziemi Mińskiej.

Hubacz, Ł. J.

2018 Wierni towarzysze. Manierki wojskowe z czasów poprzedzajacych odzyskanie przez Polskę niepodległości. Węgorzewo: Muzeum Kultury Ludowej w Węgorzewie.

Karczewska, M., Karczewski, M.

2018 Metody identyfikacji terenowej cmentarzy i mogił wojennych z czasów I wojny światowej. W: M. Karczewska (red.), Cmentarze wojenne I wojny światowej po stuleciu. Stan badań i ochrony (s. 35-46). Białystok: Ośrodek Badań Europy Środkowo-Wschodniej.

Karpus, Z., Rezmer, W.

1997 Tuchola. Obóz jeńców i internowanych 1914-1923, t. 1, cz. 1. Toruń: Wydawnictwo UMK.

Karpus, Z., Rezmer, W.

1998 Tuchola. Obóz jeńców i internowanych 1914-1923, t. 1, cz. 2: Choroby zakaźne i walka z nimi (1920-1922). Toruń: Wydawnictwo UMK. 
Karpus, Z., Wiszka, E., Sribniak, I.

2007 Tuchola. Obóz jeńców i internowanych 1914-1923, t. 1, cz. 3: Warunki życia jeńców i internowanych. Toruń: Wydawnictwo UMK.

Kiarszys, G., Szalast, G.

2014 Archeologia w chmurze punktów. Porównanie rezultatów filtracji i klasyfikacji gruntu w projekcie ISOK z wynikami opracowanym w oprogramowaniu LAStools i TerraSolid. Folia Praehistorica Posnaniensia, 18, 541-566.

Kobiałka, D.

2017 Airborne Laser Scanning and 20th Century Military Heritage in the Woodlands. Analecta Archaeologica Ressoviensia, 12, 247-269.

Kobiałka, D.

2018a 100 years Later: The Dark Heritage of the Great War at a Prisoner-of-war Camp in Czersk, Poland. Antiquity, 92(363), 772-787.

Kobiałka, D.

2018b Kreatywność za drutem kolczastym. Archeologia i sztuka okopowa z pierwszowojennego obozu jenieckiego w Czersku (woj. pomorskie). Folia Praehistorica Posnaniensia, 23, $105-136$.

Kobiałka, D.

2019 Living Monuments of the Second World War: Terrestrial Laser Scanning and Trees with Carvings. International Journal of Historical Archaeology, 23(1), 129-152.

Kobiałka, D., Kostyrko, M., Kajda, K.

2016 Archeologia poza archaīos. Przykład obozu jeńców wojennych i internowanych w Tucholi (woj. kujawsko-pomorskie). Folia Praehistorica Posnaniensia, 21, 177-200.

Kobiałka, D., Kostyrko, M., Kajda, K.

2017 The Great War and its Landscapes between Memory and Oblivion: The Case of Prisoners of war Camps in Tuchola and Czersk, Poland. International Journal of Historical Archaeology, 21(1), 134-151.

Konecki, K.

2018 Studia z metodologii badań jakościowych. Teoria ugruntowana. Warszawa: PWN.

Kostyrko, M.

2018 Biografia przeszłych krajobrazów wobec danych teledetekcyjnych [niepublikowana dysertacja doktorska]. Poznań: Instytut Archeologii UAM w Poznaniu.

Kostyrko, M., Kajda, K., Wroniecki, P., Lokś, A.

2016 Archeologia nieinwazyjna w lesie. Prospekcja wczesnośredniowiecznego grodziska w Biedrzychowicach Dolnych, woj. lubuskie. Śląskie Sprawozdania Archeologiczne, 58, 85-99.

Lawrynowicz, O.

2013 Archeologiczne weryfikacje miejsc pamięci w lasach zgierskich w latach 2011-2012. Prace i Materiaty Muzeum Miasta Zgierza, 8, 281-313.

Ławrynowicz, O., Badji, J., Majewski, M.

2017 Niemieckie zbrodnie nazistowskie w świetle badań etnoarcheologicznych. Acta Universitatis Lodziensis. Folia Archaeologica, 32, 157-189.

Łopatyńska, H. M., Szelągowska, G.

2017 (Nie)potrzebne, (nie)codzienne, (nie)inne. Reaktywacja rzeczy. Toruń: Muzeum Etnogra-

Marcinkiewicz, A. ficzne im. Marii Znamierowskiej-Prüfferowej w Toruniu.

2016 Śmiertelność jeńców wojennych w latach 1914-1918 na terenie Prus Zachodnich. Koło Historii, 19, 115-125.

Montanus, $\mathrm{H}$.

1915 Die Kriegsgefangenen in Deutschland. Gegen 250 Wirklichkeitsaufnahmen aus deutschen Gefangenenlagern mit einer Erläuterung. Siegen - Leipzig - Berlin: Hermann Montanus. 
Moshenska, G.

2007 Oral History in Historical Archaeology: Excavating Sites of Memory. Oral History, 35(1), 91-97.

Mytum, H., Carr, G. (red.)

2013 Prisoners of War: Archaeology, Memory, and Heritage of 19th- and 20th-Century Mass Internment. New York: Springer.

Nora, P., Kritzman, L. D. (red.)

1996 Realms of Memory: Conflicts and Divisions. New York: Columbia University Press.

Saunders, N.

2000 Bodies of Metal, Shells of Memory: 'Trench Art', and the Great War Re-cycled. Journal of Material Culture, 5, 43-67.

Saunders, N.

2003 Trench Art: Materialities and Memories of War. Oxford: Berg.

Saunders, N.

2010 Killing Time: Archaeology and the First World War. Stroud: Sutton.

Saunders, N.

2016 'Pearl's Treasure': The Trench Art collection of an Australian Sapper. W: L. Slade (red.), Sappers and Shrapnel: Contemporary Art and the Art of the Trenches (s. 12-39). Adelaide: Art Gallery of South Australia.

Szwankowski, J.

2010 Tuchola od 1815 do 1920 roku. W: W. Jastrzębski, J. Szwankowski (red.), Tuchola. Od pradziejów do wspótczesności (s. 207-360). Bydgoszcz - Tuchola: Miejska Biblioteka Publiczna w Tucholi.

Sturdy Colls, C.

2015 Holocaust Archaeologies: Approaches and Future Perspectives. New York: Springer.

Wężyk, P. (red.)

2014 Podręcznik dla uczestników szkoleń z wykorzystaniem produktów LiDAR. Warszawa:

Główny Urząd Geodezji i Kartografii.

Wroniecki, P., Jaworski, M., Kostyrko, M.

2015 Exploring Free LiDAR Derivatives. A User's Perspective on the Potential of Readily Available Resources in Poland. Archaeologia Polona, 53, 611-616.

Zapłata, R., Szady, B., Stefańczyk, K. (red.)

2014 Laserowi odkrywcy - nieinwazyjne badania i dokumentowanie obiektów archeologicznych $i$ historycznych województwa świętokrzyskiego. Babice: Fundacja Centrum Geohistorii.

\section{ARCHAEOLOGY, ART, MEMORY: ARCHAEO-ETHNOGRAPHY AND TRENCH ART FROM A PRISONER OF WAR AND INTERMENT CAMP IN TUCHOLA, POLAND}

\section{Sum mary}

Material heritage of the Great War (1914-1918) consists of an astonishing variety of objects and their fragments, sites, up to and including whole landscapes devastated during the conflict. Its part are also remains of prisoner of war camps which have recently become the subject of various archaeological, historical, and ethnographic research.

One of the German prisoner of war camps during the Great War was opened in Tuchola, West Prussia (in German Kriegsgefangenenlager Tuchel). The site was built to imprison Russian soldiers 
taken into captivity in August and September 1914 in East Prussia. While the war was continuing during the next months and years, Romanian, Italian, British, and American soldiers were detained in Tuchola as well. In 1918, Tuchola and the whole region became part of reborn new Polish state. After the war the former prisoner of war camp was reused by the Polish Army. It was the site where Russian soldiers taken into captivity during the Polish-Soviet War (1919-1921) were held. The camp was also used as an interment site for a small number of Russian, Ukrainian soldiers and civilians between 1921 and 1923. In general, this paper shortly summaries the broader context, applied methodology and some of the preliminary results of historical, archaeological, and ethnographic research concerning the state of preservation of the camp heritage. In particular, the article focuses on one category of the camp heritage in which archaeology, art, and memory interwoven on many levels. This category of the camp materiality are objects which can be conceived as examples of so-called trench art.

The archaeological non-invasive research concerning the camp materiality and its state of preservation has been carried out for the last few years. The first and most important part of it relied on LiDAR technology. It is important to note that the Polish government platform named geoportal. gov.pl has been giving an open access to its LiDAR-derivatives (shade model) collected as part of the ISOK programme (in Polish Informatyczny System Ostony Kraju przed nadzwyczajnymi zagrożeniami; in English IT System of Country's Protection Against Extreme Hazards) since 2012. In 2014 the first remains of the former prisoner of war and internment camp in Tuchola were discovered while researching the shade model available at the geoportal. The discovery was the beginning of research concerning the state of preservation of various categories of remains related to opening, functioning, and final closing of the camp.

In the first part of the paper, it is argued that the use of the historical and material records can supplement each other. More than 200 camp's structures were documented due to the analysis of LiDAR-derivatives. The value of research hinges on the fact that the registered structures were not drawn on a blueprint of the camp prepared in 1916. Other remains of camp's dugouts were registered on aerial photographs taken as part of the research as well. The use and integration of the historical and material (archaeological) records were just one part of the research. The second was based on the use of ethnographic methods. Indeed, the paper tries to prove that archaeological research concerning such sites as the Tuchola camp has always make use of ethnographic methods (e.g. in-depth interview).

The application of ethnographic methods enabled to gather data that which otherwise would be impossible to collect during non-invasive archaeological research (analysis of LiDAR-derivatives and field verification) as well as archive searches. Ethnographic methods can give interesting results even in the context of the Great War when people who experienced the conflict first-hand are already dead for many decades. Ethnography offers methods to tract the past and present meanings of the camp heritage for local communities. Without any doubt, this should be a crucial aspect of every archaeological research regarding the role of meaning of material heritage of the recent past. Indeed, such research regarding material remains of the recent past can be called - as some archaeologists would have put it - archaeo-ethnography. This paper tries to present the value of such archaeo-ethnography taking as a case study a selected category of the Tuchola camp heritage.

It has to be clearly pointed out that one of the most important results of such archaeo-ethnography of the prisoner of war and internment camp in Tuchola was the discovery and documentation of objects that were family heirlooms after those who were either prisoners of war, internees, or guards in the camp. Many of these objects were hand-made. Such artefacts which were made, remade or personalized by soldiers, prisoners of war or even civilians from war materials have a very precise definition in archaeology. Such objects are examples of trench art. Similarly, various ways of commemoration of conflicts in form of e.g. monuments have to be conceived as materialization of trench 
art. That is why the second part of this paper shortly characterizes that trench art is and discusses the definition proposed some time ago by the British archaeologist and cultural anthropologist Nicholas Saunders.

The last and main part of the paper is a case study of a few examples of trench art related to the camp. Relying on the historical records and making use of the data collected during the archaeological and ethnographic research various manifestations of the Tuchola trench are analyzed. Among them were e.g. a photograph presenting a dugout painted by prisoners at the camp, monument at the camp cemetery, fragment of photo frame made of fragment of aluminum plate, brooch made of two 10 kopek coins, patriotic ring, wooden case up and including hand-made postcards made by most probably some German guards of the camp and painting drawn by a Russian interned between 1919 and 1921 in Tuchola. Although the discussed assemblage of the Tuchola trench art is small and random, it materializes the ways how people, both prisoners of war as well as their German guards, creatively used and reused every piece of material culture during the war. Trench art memories human responses to the war through a creative use of material culture.

The analyzed trench art shows the fact that many functions, meanings, and values have were attributed to it. It materializes at the same time the astonishing variety of objects that can be defined as trench art. For example, decorating dugouts by prisoners of war at the camp can be interpreted as an attempt of domesticating other space which, without any doubts, was the Tuchola camp for the prisoners. Such creative practices which make use of own cultural, artistic landscape of fatherland can be seen as an element of strategy of surviving the time in Tuchola. Trench art does not have to be literally an artefact. Buildings decorated by prisoners of war are part of assemblage of trench art. The same holds for various ways of commemoration of those who died during military conflicts. Concerning the Tuchola camp, a monument erected at the camp cemetery is a good example of it. It was built by three Polish prisoners who served in the Russian army. As an inscription on the monument states, the obelisk was built for the memory of those who died in the camp. The function of trench art as material and durable form of commemoration of the dead is another important characteristic of trench art, including the Tuchola camp.

However, trench art usually consists of small, banal, ordinary objects that were made of various materials available to prisoners of war, soldiers, and civilians during wars. As a typical artefact of this category can be mentioned a fragment of aluminum plate documented during field surveying the structures documented on LiDAR-derivatives. The object is a L-shape, it has $2 \times 2,5 \mathrm{~cm}$. Marks of cutting the plate are well visible. Additionally, carvings cover the object. The artefact is out of a proper archaeological context. However, one of the interpretations is that it is a fragment of photo frame made of a piece of aluminum object (e.g. canteen, mess tin). It could be used as frame of photographs presenting e.g. wife or children of an anonymous prisoner detained in Tuchola. It is known from many sources that such objects as photographs presenting families of prisoners of war were of greatest values for the detained. Such objects helped in many cases to survive long days, weeks, months, and years of imprisonment behind barbed wire. They were a kind of material bridge between the past and present situation of the imprisoned soldiers that enable to keep faith in returning to home. Such banal things as a fragment of cut and decorated plate can give glimpse into the social and cultural life of prisoners of war - their hopes, fears, emotions.

Another category of trench art documented during the archae-ethnographic research consists of artefacts that are family heirlooms after those who were either imprisoned at the camp or were camp guards. An in-depth interview with Jerzy Szwankowski, a civilian who lives in Tuchola, is a telling example. A grandfather of Szwankowski's wife was a guard during the Great War at the camp. He passed away, however some of artefacts what were possessed by him were preserved by the family. Among the objects are a brooch made of two 10 kopek coins, patriotic ring, and wooden case, among other things. It is more that possible that all three artefacts were made by one or more prison- 
ers of war detained at the Tuchola camp. Each of the things is hand-made. Once again, it is known from memories of many prisoners of war detained during the Great War that imprisoned soldiers made objects to trade them with guards. Prisoner of war could exchange the brooch, the ring, and the wooden case for e.g. cigarettes, food, or alcohol with a grandfather of Szwankowski's wife. Each artefact shows at the same time artistic skills of imprisoned soldiers. Another relevant observation to make is that the items point out the fact that trench art could be very important for contemporary people. Objects that are family heirlooms are an excellent example of it. They are memory objects that link the past of the Tuchola camp with the present. It can be said that the past of the Tuchola camp is alive and present through such objects and memories related to them.

Finally, examples of trench art made most probably by German guards at the camp were also documented during the field research. Another in-depth interview was carried out with Zenon Wędzicki. He is a regionalist who collects German propaganda postcards presenting the Tuchola camp, among other things. A part of the collection are three postcards which were hand-made. They are simple drawings presenting Russian prisoners plus one postcard made of birch bark. These arefacts should also be seen as example of trench art because they were made during the conflict and document a certain aspect of the Great War.

In conclusion, trench art is a kind of material memory that gives glimpse into often undiscursive and forgotten aspects of war times and their social, cultural, and material consequences. The value of this paper is that it is a first archaeological study that focuses on trench art related to the Tuchola camp. For many decades, as the results of archaeo-ethnography of the Tuchola camp indicate, objects made, remade, personalized by the prisoners as well as their guards have been the aim of illegal treasure hunting. In short, trench art is nothing more than a peculiar materialization of the archaeological record. Researching it requires a multidisciplinary framework that combines archaeology, history, and ethnography. 